\title{
Identification of specific interaction of juvenile hormone binding protein with isocitrate dehydrogenase
}

\author{
Marta Zalewska ${ }^{1,2}$, Andrzej Ożyhar ${ }^{1}$ and Marian Kochman ${ }^{1 凶}$ \\ ${ }^{1}$ Department of Biochemistry, Faculty of Chemistry, Wroclaw University of Technology, Wrocław, Poland; ${ }^{2}$ Department of Biomedical and Envi- \\ ronmental Analysis, Faculty of Pharmacy, Wroclaw Medical University, Wrocław, Poland
}

\begin{abstract}
Juvenile hormone $(\mathrm{JH})$ is essential for multiple physiological processes: it controls larval development, metamorphosis and adult reproduction. In insect hemolymph more than $99 \%$ of $\mathrm{JH}$ is bound to juvenile hormone binding protein (JHBP), which protects $\mathrm{JH}$ from degradation by nonspecific hydrolases and serves as a carrier to supply the hormone to the target tissues. In Galleria mellonella hemolymph, JHBP is found in a complex with lipid-binding high molecular weight proteins (HMWP) and this interaction is enhanced in the presence of $\mathrm{JH}$. In this report, we present studies on the interaction of JHBP with low molecular weight proteins (LMWP) in the hemolymph. Using ligand blotting we found that JHBP interacts with a protein of about $44 \mathrm{kDa}$. To identify the protein that preferentially binds JHBP, a LMWP fraction was applied to a Sepharose-bound JHBP and, after washing, the column was eluted with free JHBP acting as a specific competitor or with carbonic anhydrase as a negative control. The eluted proteins were separated by SDS/PAGE and analyzed by mass spectrometry. Isocitrate dehydrogenase was identified as a component of the supramolecular complex of JHBP with hemolymph proteins.
\end{abstract}

Keywords: JHBP, protein-protein interaction

Received: 01 September, 2010; revised: 23 December, 2010; accepted: 24 December, 2010; available on-line: 14 March, 2011

\section{INTRODUCTION}

Juvenile hormone binding protein (JHBP) transports juvenile hormone (JH) from corpora allata to target cells and serves as a pool of $\mathrm{JH}$ in the hemolymph. JH regulates growth, development, metamorphosis and also stimulates reproduction of insects. The presence of $\mathrm{JH}$ maintains insects in the larval stage and its absence allows metamorphosis to occur (Gilbert et al., 2000). In hemolymph, three separate groups of proteins may bind $\mathrm{JH}$, lipophorins, hexameric proteins, and low molecular weight proteins of approximately $30 \mathrm{kDa}$. The most abundant high molecular weight lipophorins with up to $50 \%$ lipid content belong to the family of large lipid transfer (LLT) proteins and contain two or three apolipoproteins: apolipophorin I (apoLp-I), apolipophorin II (apoLp-II) and apolipophorin III (apoLp-III) with molecular weights of about 220-250, 80, and 17-20 kDa, respectively. The second group of high molecular weight proteins with about $15 \%$ lipid content belongs to the superfamily of hexameric larval hemolymph proteins (LHP) (Gilbert et al., 2000). The third group of JH binding proteins, low molecular weight JHBP $(25-32 \mathrm{kDa})$, is of special interest as these proteins bind $99 \%$ of $\mathrm{JH}$ in the hemolymph despite constituting below $1 \%$ of the total protein content of hemolymph (Hidayat \& Goodman, 1994).

Lepidopteran JHBPs are monomeric with the molecular mass in the range $25-35 \mathrm{kDa}$ (Kort \& Granger, 1996). JHBP from Galleria mellonella is a glycoprotein (Duk et al., 1996). Structurally it resembles the folding pattern of some mammalian lipid-binding proteins, namely bactericidal permeability-increasing protein (BPI) and cholesteryl ester transfer protein (CETP), with a similar organization of one cavity and a disulfide bond between a long helix and a $\beta$-sheet. JHBP reveals, therefore, a fold used by nature for hydrophobic-ligand binding proteins (Kolodziejczyk et al., 2008). The JHBP molecule undergoes a profound conformational transition upon binding $\mathrm{JH}$ as judged from its changing electrophoretic mobility, UV spectra, sedimentation coefficient and its resistance against proteolysis (Wieczorek \& Kochman, 1991; Krzyżanowska et al., 1998). It has been suggested that such a structural change might have a physiological significance for hormone signal transmission (Wieczorek \& Kochman, 1991).

The concentration of hemolymph proteins often exceeds $100 \mathrm{mg} / \mathrm{ml}$ (Ożyhar \& Kochman, 1987). This creates favorable conditions for protein-protein interactions, some of which might be functional. In $G$. mellonella hemolymph, JHBP is found in a complex with lipid binding proteins of high molecular weight, apolipophorin, arylphorin and hexamerin (Zalewska et al., 2009). These proteins bind JHBP, both free and in a complex with JH. However, this binding is stronger in the presence of JH. It has also been shown that JHBP binds to fat body membrane proteins. ATP synthase has been identified as a JHBP binding protein and this interaction is specific and occurs with high affinity $\left(K_{\mathrm{d}}=0.86 \mathrm{nM}\right)$ (Zalewska et al., 2009).

In this report, we focused our attention on low molecular weight proteins (LMWP) which might be bound to JHBP. Two types of experiments were designed: ligand blotting and JHBP affinity chromatography. By the use of ligand blotting, we found that JHBP interacts with a protein of about $44 \mathrm{kDa}$. Using Sepharose-coupled JHBP column chromatography and mass spectrometry analysis, we have identified NADP dependent isocitrate dehydrogenase (NADP-IDH) as a JHBP binding protein. Interaction of JHBP with NADP-IDH may be involved

e-mail: marian.kochman@pwr.wroc.pl

Abbreviations: HMWP, high molecular weight proteins; IDH, isocitrate dehydrogenase; JH, juvenile hormone; JHBP, juvenile hormone binding protein; LMWP, low molecular weight proteins 
in the formation of a complex with other hemolymph proteins but further studies are needed to determine the role of this interaction.

\section{MATERIALS AND METHODS}

Chemicals. Juvenile hormone III (10R,S-JH III) was purchased from Sigma. $10-\left[{ }^{3} \mathrm{H}\right]$-labeled JH III was purchased from Polatom (Poland).

Insects. Galleria mellonella (Lepidoptera, Pyralidae) larvae were reared in constant darkness at $30^{\circ} \mathrm{C}$ on a semiartificial diet prepared as described by Sehnal and Slama (1966).

Purification of juvenile hormone binding protein and juvenile hormone binding activity assay. The hemolymph from 4th day, VIIth instar larvae was collected into a plastic tube containing a few crystals of 1-phenyl2-thiourea and stored at $-20^{\circ} \mathrm{C}$.

JHBP was purified from hemolymph by immunoaffinity chromatography (Wieczorek et al., 1996). The JHbinding activity was determined with a charcoal assay in the presence of $0.1 \%$ gelatin, as described previously (Ożyhar \& Kochman, 1987).

Separation of hemolymph low molecular weight proteins (LMWP) from high molecular weight proteins (HMWP). Seven milliliters of hemolymph was applied onto a Sephadex G-200 column (K 16/100, Pharmacia) equilibrated with $10 \mathrm{mM}$ Tris buffer, $100 \mathrm{mM}$ $\mathrm{NaCl}, 0.25 \mathrm{mM}$ 1-phenyl-2-thiourea, pH 7.3. The flow rate was $17 \mathrm{ml} / \mathrm{h}$ and $7-\mathrm{ml}$ fractions were collected. Fractions from the ascending part of the second absorption peak $\left(\mathrm{A}_{280}\right)$, containing LMWP (Fig. 1A), were combined and used for ligand blotting analysis.

SDS polyacrylamide gel electrophoresis. Proteins were separated by sodium dodecyl sulfate polyacrylamide
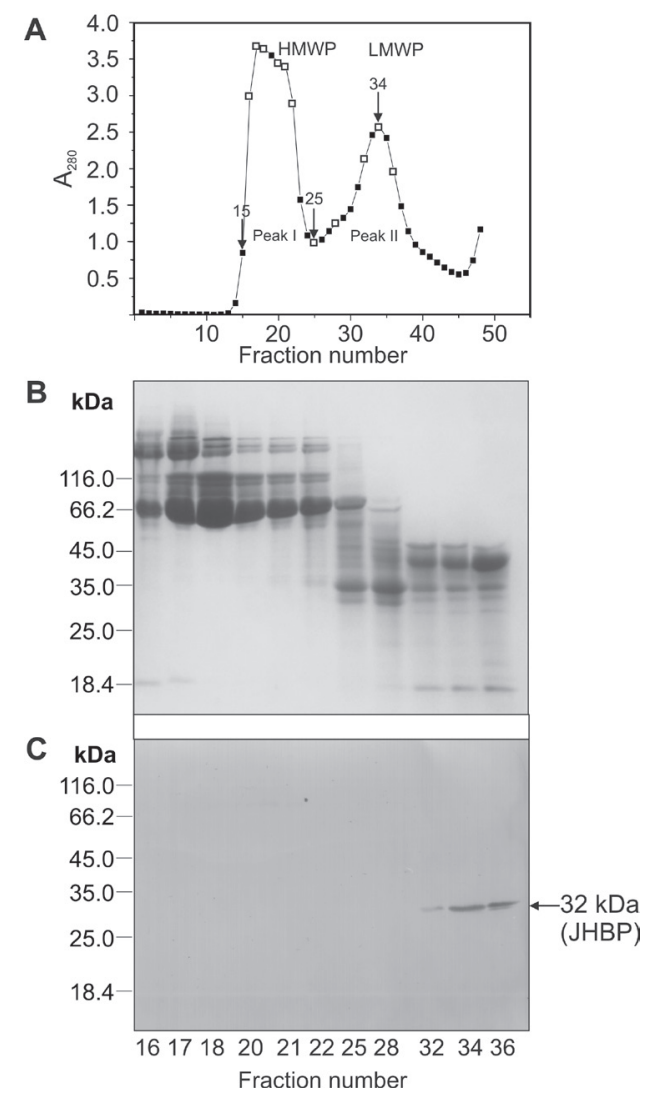

gel electrophoresis (SDS/PAGE) (Laemmli, 1970) under reducing or non-reducing conditions. To obtain non-reducing conditions, we did not boil the sample and reducing agents were not added to minimize irreversible protein denaturation. Gels consisted of a $4 \%$ stacking gel and a 12\% resolving gel. Electrophoresis was carried out until the dye front reached the bottom of the gels. Gels were stained with Coomassie Brilliant Blue R or with silver for visual observation (Shevchenko et al., 1996).

Western blotting. Proteins were separated by SDS/ PAGE under reducing conditions and were transferred to nitrocellulose transfer membrane (Millipore) for $1 \mathrm{~h}$ at $150 \mathrm{~V}$. The membranes containing transferred proteins were first incubated in a buffer $(10 \mathrm{mM}$ Tris, $150 \mathrm{mM} \mathrm{NaCl}, \mathrm{pH} \mathrm{7.5,} \mathrm{supplemented} \mathrm{with} 3 \%$ non-fat dry milk) for $1 \mathrm{~h}$ at $25^{\circ} \mathrm{C}$. After blocking, the nitrocellulose membranes were treated with a 1:25000 dilution of polyclonal anti-JHBP. Polyclonal antibodies against JHBP were obtained as previously described (Rodriguez Parkitna et al., 2002). Then, the membranes were washed three times with the buffer and incubated with 1:5000 dilution of goat anti-rabbit polyclonal antibodies conjugated with horseradish peroxidase (HRP) (Sigma). The Western blotting assay was developed using a peroxidase detection kit (ECL plus Western Blotting Detection System, Amersham).

Ligand blotting. Proteins were separated by SDS/ PAGE under non-reducing conditions and were transferred to nitrocellulose membrane (Towbin et al., 1979) for $1 \mathrm{~h}$ at $150 \mathrm{~V}$. The membranes containing transferred proteins were first incubated in a blocking buffer as described above. After blocking, the membranes were incubated for $1 \mathrm{~h}$ in a $10 \mathrm{mM}$ Mops, $100 \mathrm{mM} \mathrm{NaCl}$ $\mathrm{pH} 7.2$ buffer containing either JHBP (1 $\mathrm{mg} / \mathrm{ml})$ or JHBP $(1 \mathrm{mg} / \mathrm{ml}$ ) plus $20 \mu \mathrm{M} \mathrm{JH}$ (preincubated for $0.5 \mathrm{~h}$ at $\left.4^{\circ} \mathrm{C}\right)$ or with BSA $(1 \mathrm{mg} / \mathrm{ml})$ as a negative control. Next, the membranes were washed three times with the buffer, and afterwards treated with a 1:25000 dilution of polyclonal anti-JHBP and washed again three times with the buffer. Then, the membranes were incubated with 1:5000 dilution of goat anti-rabbit polyclonal antibodies conjugated with horseradish peroxidase (HRP) (Sigma). The ligand blotting assay (Daniel et al., 1983) was developed using a peroxidase detection kit (ECL plus Western Blotting Detection System, Amersham).

Coupling of CNBr-activated Sepharose with JHBP. JHBP was coupled to Sepharose beads accord-

Figure 1. Gel filtration chromatography of hemolymph proteins on Sephadex G-200 and analysis of the presence of juvenile hormone binding protein (JHBP) in the obtained fractions (A) Sephadex G-200 chromatography. Seven milliliters of hemolymph from $G$. mellonella was subjected to gel filtration on Sephadex G-200 column (K26/100, Pharmacia) equilibrated and eluted with stock buffer $(10 \mathrm{mM}$ Tris, $100 \mathrm{mM} \mathrm{NaCl}, \mathrm{pH}$ 7.3) containing $0.25 \mathrm{mM} 1$-phenyl-2-thiourea. Fractions of $7 \mathrm{ml}$ were collected. Selected fractions (open squares) were applied to SDS electrophoresis. Fractions (15 to 24 ) from the first absorption peak contained HMWP. Fractions (25 to 34 ) from the ascending part of the second absorption peak indicated by arrows were combined (representing a portion of LMWP) and used in further experiments (see Fig. 2). (B) SDS/PAGE analysis. Fractions obtained by gel filtration (40 $\mathrm{\mu g}$ protein/lane) were subjected to SDS/PAGE and stained with Comassie Brilliant Blue. (C) Western blotting analysis. Fractions eluted from Sephadex G-200 column were separated by SDS/PAGE (40 $\mu \mathrm{g}$ protein/lane) and then transferred to nitrocellulose membrane. The membrane was treated with polyclonal antibodies against JHBP $(1: 25000)$. Binding was visualized with secondary goat anti-rabbit HRP-conjugated antibody (1:5000) and a chemiluminescence system. Arrow indicates position of JHBP (32 kDa). 
ing to the manufacturer's instructions (Sigma). Briefly, $1 \mathrm{mg}(0.75 \mathrm{ml})$ of JHBP in $0.1 \mathrm{M} \mathrm{NaHCO}, \mathrm{pH} 8.3$, was mixed with $0.25 \mathrm{ml}$ of $\mathrm{CNBr}$-activated Sepharose beads in suspension and left overnight at $4{ }^{\circ} \mathrm{C}$ with gentle shaking. After washing with the buffer and blocking with ethanolamine, $\mathrm{pH} 8.0$, the beads were stored in $0.04 \%$ $\mathrm{NaN}_{3}$ at $4^{\circ} \mathrm{C}$ before use.

Affinity chromatography on JHBP-Sepharose. Hemolymph proteins were separated on a Sephadex G-200 column equilibrated with a $10 \mathrm{mM}$ Mops, $100 \mathrm{mM}$ $\mathrm{NaCl}$ buffer, $\mathrm{pH}$ 7.2, and fractions designated as LMWP were combined from the ascending part of the second $280 \mathrm{~nm}$ absorption peak (Fig. 1A). Ten milliliters of LMWP $(1.8 \mathrm{mg} / \mathrm{ml})$ was incubated with $0.2 \mathrm{ml}$ of a suspension of Sepharose-bound JHBP. After incubation for $1 \mathrm{~h}$ at $4^{\circ} \mathrm{C}$, the beads were washed with 6 vol. of the buffer and the bound protein complexes were eluted by competitive elution with JHBP $(0.3 \mathrm{mg}, 0.4 \mathrm{ml})$ or with carbonic anhydrase $(0.33 \mathrm{mg}, 0.4 \mathrm{ml})$ as a negative control. Eluted proteins were applied to SDS/PAGE and detected by Coomassie Blue staining and silver staining. Protein bands were excised and identified using tandem mass spectrometry (MS).

Mass spectrometry and database searching. The peptide mixture obtained by a standard in-gel tryptic digestion procedure (including reduction and alkylation) was applied to an RP-18 precolumn (Waters, NanoACQUITY, $20 \mathrm{~mm} \times 180 \mu \mathrm{m})$ using water containing $0.1 \%$ trifluoroacetic acid as a mobile phase and then transferred to a UPLC RP-18 column (Waters, NanoACQUITY, $250 \mathrm{~mm} \times 75 \mu \mathrm{m}$ ) using an acetonitrile gradient $(0-60 \%$ in $120 \mathrm{~min})$ in the presence of $0.05 \%$ formic acid at a flow rate of $150 \mathrm{nl} / \mathrm{min}$. The column outlet was directly coupled to the ion source of an Ion $\mathrm{Cy}$ clotron Resonance spectrometer (LTQ-FTICR, Thermo Electron) working in the regime of data-dependent MS to MS/MS switch. The resulting mass spectra were used to search the nonredundant protein database of the $\mathrm{Na}$ tional Center of Biotechnology Information (NCBI version 20080422) using the MASCOT (matrixscience.com) search engine (eight-processor on-site license). Protein mass was unrestricted. The search parameters for peptide mass tolerance were $\pm 40 \mathrm{ppm}$ and for fragment mass tolerance $\pm 0.8 \mathrm{Da}$, with an allowance made for one missed semiTrypsin, fixed modifications of cysteine through carbamidomethylation and variable modification through methionine oxidation.

The above MS analysis and database search was performed by the Laboratory of Mass Spectrometry, Institute of Biochemistry and Biophysics, Polish Academy of Sciences, Warszawa, Poland.

\section{RESULTS}

\section{Gel filtration chromatography of hemolymph proteins and JHBP profile}

Hemolymph proteins from $G$. mellonella were fractionated on a Sephadex G-200 column and separated into two main $\mathrm{A}_{280}$ absorption peaks, the first containing HMWP and the second LMWP, as shown in Fig. 1A. Then, the protein fractions were analyzed by SDS/ PAGE (Fig. 1B) and Western blotting (Fig. 1C) to detect JHBP. JHBP was found primarily in fractions 34-36. A very weak band was also present in fraction 32 . In the conditions of this experiment, JHBP does not comigrate with proteins of higher molecular weight. For analysis

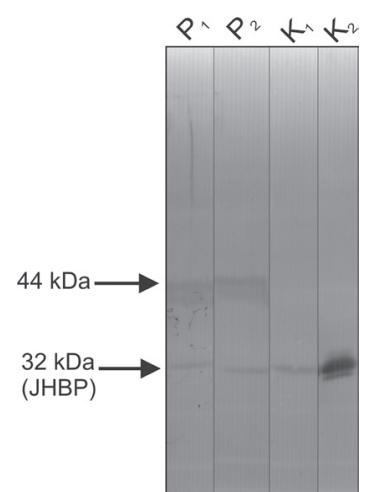

Figure 2. Ligand blotting analysis of JHBP or JHBP-JH complex binding to hemolymph LMWP

LMWP $\left(40 \mu \mathrm{g}\right.$ ) (lanes: $\mathrm{P}_{1}, \mathrm{P}_{2}$ and $\mathrm{K}_{1}$ ) and $0.2 \mu \mathrm{g}$ of JHBP (lane: $\mathrm{K}_{2}$ ) were separated by SDS/PAGE under non-reducing conditions designed to minimize irreversible protein denaturation and were transferred to nitrocellulose membrane. The binding experiment was performed in the absence (lane $K_{1}$ ) or presence of JHBP (lane $\mathrm{P}_{1}$ ) or JHBP-JH complex (lane $\mathrm{P}_{2}$ ) as ligands. The membrane was treated with polyclonal antibodies against JHBP (1:25000). Binding was visualized with HRP-goat anti-rabbit (1:5000) as a secondary antibody and a chemiluminescence system. Arrows indicate positions of protein interacting with JHBP and JHBP-JH complex (44 kDa) and of free JHBP (32 kDa).

of the interaction of LMWP with JHBP fractions 25-34 were combined and used for ligand blotting experiments.

\section{Ligand blotting analysis reveals a protein interacting with JHBP}

In order to determine whether JHBP may interact with a protein(s) present in the LMWP fraction, a ligand blotting analysis was performed (Daniel et al., 1983). As shown in Fig. 2, among several proteins present in this fraction (Fig. 1B), only a protein band of about $44 \mathrm{kDa}$ interacts with JHBP and its position is clearly distinct from that of JHBP detected in LMWP or in control sample (Fig. 2, compare lanes $\mathrm{P}_{1}$ and $\mathrm{K}_{1}$ ). An analogous experiment performed in the presence of $\mathrm{JH}$ revealed almost the same intensity of the $44 \mathrm{kDa}$ band in the

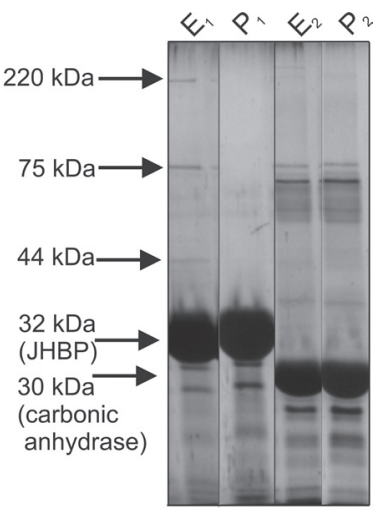

Figure 3. Interaction between LMWP and JHBP analyzed by affinity chromatography

LMWP (18 mg in $10 \mathrm{ml}$ ) was incubated with JHBP immobilized on Sepharose beads $(0.2 \mathrm{ml})$. After incubation the beads were exhaustively washed. Proteins eluted by JHBP $(0.3 \mathrm{mg}, 0.4 \mathrm{ml})$ or carbonic anhydrase $(0.33 \mathrm{mg}, 0.4 \mathrm{ml})$ as specific and nonspecific competitors are shown in lane $E_{1}$ and $E_{2}$ respectively. Eluates $(28 \mu \mathrm{l})$ were analyzed by SDS/PAGE and stained with silver reagent. JHBP (lane $P_{1}$ ) and carbonic anhydrase (lane $P_{2}$ ) used for elution were electrophoresed to show their mobility. Arrows indicate positions of JHBP-binding proteins (220, 75 and $44 \mathrm{kDa})$ and competitors, JHBP (32 kDa) and carbonic anhydrase (30 kDa). 
Table 1. JHBP-binding hemolymph protein isolated by affinity chromatography and identified using tandem mass spectrometry

\begin{tabular}{|c|c|c|c|c|c|}
\hline $\begin{array}{l}M_{r} \\
\text { SDS/PAGE [kDa] }\end{array}$ & $\begin{array}{l}\text { Protein } \\
\text { (organism) }\end{array}$ & $\begin{array}{c}\mathrm{NCBI} \\
\text { Accession number }\end{array}$ & $\begin{array}{l}\text { Calculated } M_{\mathrm{r}} \\
{[\mathrm{kDa}]}\end{array}$ & $\begin{array}{l}\text { No. of peptides } \\
\text { identified }\end{array}$ & $\begin{array}{c}\text { Sequence coverage } \\
{[\%]}\end{array}$ \\
\hline 44 & $\begin{array}{l}\text { Isocitrate dehydrogenase } \\
\text { (Bombyx mori) }\end{array}$ & Q2F681 & 46.2 & 4 & 12.25 \\
\hline
\end{tabular}

LMWP fraction interacting with JHBP (Fig. 2, compare lane $\mathrm{P}_{1}$ with $\mathrm{P}_{2}$ ). Small differences in the electrophoretic mobilities between samples $\mathrm{P}_{1}$ and $\mathrm{P}_{2}$ are due to imperfections in electrophoretic conditions. In a control experiment, where bovine serum albumin (BSA) was used instead of JHBP, no binding of the antibody against JHBP to the $44 \mathrm{kDa}$ protein was observed (Fig. 2, lane $\mathrm{K}_{1}$ ). For comparison, the electrophoretic mobility of purified JHBP is shown in lane $\mathrm{K}_{2}$. Its microheterogeneity is due to different extents of glycosylation of hemolymph JHBP (Duk et al., 1996).

Identification of JHBP-binding protein with affinity chromatography and mass spectrometry analysis

Affinity chromatography was used to confirm that the hemolymph LMWP fraction contains a protein which binds JHBP. Combined LMWP fractions (from the ascending part of the second absorption peak, see Fig. 1A) were applied on a JHBP-Sepharose column and after excessive washing with a buffer, the column was eluted with JHBP acting as a specific competitor or with carbonic anhydrase as a control (nonspecific) ligand. The eluted proteins were separated by SDS/PAGE and analyzed by mass spectrometry. For control elution we chose carbonic anhydrase because in SDS/PAGE this protein is clearly separated from JHBP and from the protein of about $40 \mathrm{kDa}$ present in LMWP. When the gel was stained with Coomassie Brilliant Blue, only traces of bands corresponding to molecular masses of $220 \mathrm{kDa}$ and $75 \mathrm{kDa}$ were detected as eluted by JHBP (not shown). Because of that, silver staining, a more sensitive method of protein detection, was used. Analysis of the SDS/PAGE results after silver staining revealed three distinct protein bands eluted by JHBP (Fig. 3, lane $\left.\mathrm{E}_{1}\right)$. Their positions correspond to molecular masses: $220 \mathrm{kDa}, 75 \mathrm{kDa}$ and $44 \mathrm{kDa}$. The protein bands corresponding to $220 \mathrm{kDa}$ and $75 \mathrm{kDa}$ have already been identified as HMWP interacting with JHBP (Zalewska et al., 2009). In the LMWP fraction a new band of $44 \mathrm{kDa}$ was identified. This protein band was excised from the gel and subjected to ESI-FTICR-MS analysis and identified as NADP-dependent isocitrate dehydrogenase (Table 1, Fig. 4). The mass spectrometric analysis detected 50 of the 408 amino acids of isocitrate dehydrogenase $(12.25 \%)$, basing on the amino-acid sequence from Bombyx mori (Lepidoptera). The genomic sequence or the amino-acid sequence of the enzyme for $G$. mellonella are not known yet.

\section{DISCUSSION}

As shown above the affinity chromatography of LMWP on JHBP-Sepharose column revealed three protein bands specifically eluted by JHBP and several other

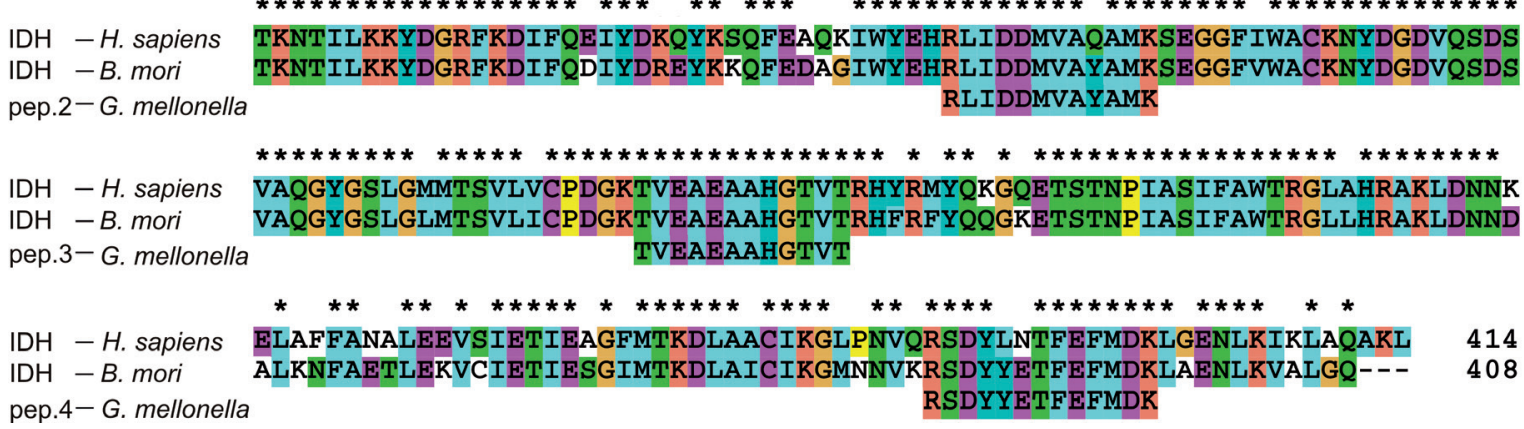

Figure 4. Amino-acid sequence comparison of human and silk moth cytosolic NADP-IDH and of the peptides obtained from MS analysis

Amino-acid sequences of cytosolic NADP-IDH from Homo sapiens (O75874) and B. mori (Q2F681) and four peptides derived from $44 \mathrm{kDa}$ protein band (pep. 1, 2, 3, 4-G. mellonella) were aligned using the ClustalW program (Thompson et al., 1994). "**" denotes identical residues. 
nonspecifically eluted bands that were present in the JHBP and carbonic anhydrase eluates. Positions of the specifically eluted protein bands correspond to molecular masses: $220 \mathrm{kDa}, 75 \mathrm{kDa}$ and $44 \mathrm{kDa}$. The proteins corresponding to $220 \mathrm{kDa}$ and $75 \mathrm{kDa}$ have already been identified as interacting with JHBP (Zalewska et al., 2009). The protein band of $220 \mathrm{kDa}$ corresponds to an apolipophorin subunit, the major component of lipophorin, which mediates the transport of various types of lipids in the hemolymph. The protein band of $75 \mathrm{kDa}$ is an arylphorin subunit belonging to the superfamily of hexameric larval hemolymph proteins (LHP).

As judged from tandem mass spectrometry and database searches, four peptides identified from the protein of $44 \mathrm{kDa}$ have sequences identical with NADP dependent isocitrate dehydrogenase (IDH) from B. mori (Fig. 4). These peptides cover $12.25 \%$ of the enzyme sequence composed of 408 amino-acid residues. Although G. mellonella IDH primary structure is not known, it is noteworthy that IDH sequence is highly conserved during evolution (Fig. 4). In eukaryotic organisms, the NADP-IDHs represent a highly conserved group of proteins. Substantial degree of identity of the aminoacid sequence is observed between the cytosolic and mitochondrial forms of the enzyme as well as between organisms with different phylogenetic origins. B. mori cytosolic NADP-IDH compared with the human cytosolic form of NADP-IDH is $76 \%$ identical (Fig. 4). Therefore, based on the MS data we believe that NADP dependent isocitrate dehydrogenase is the protein found in a complex with JHBP.

Eukaryotic cells express different isoforms of isocitrate dehydrogenase (IDH), an enzyme which catalyzes the oxidative decarboxylation of isocitrate to $\alpha$-ketoglutarate utilizing either NAD or NADP as cofactors. NAD-dependent IDH (EC 1.1.1.41) is a mitochondrial enzyme and its role is well known, as it catalyzes a key step in the tricarboxylic acid cycle. It is composed of $\alpha, \beta$, and $\gamma$ subunits, and the enzyme is allosterically regulated by ADP (Ceccarelli et al., 2002). The physiological roles of the NADP-dependent IDHs (NADP-IDHs) (E.C.1.1.1.42), which function as homodimers, are not clearly understood. NADP-IDHs are present in mitochondria, cytoplasm and peroxisomes. Mitochondrial NADP-IDH is an additional source of $\alpha$-ketoglutarate and NADPH (Jo et al., 2001; Contreras-Shannon et al., 2005). Non-mitochondrial NADP-IDHs apparently function to provide NADPH for biosynthetic reactions and for thiol-based antioxidant systems (Lu et al., 2008). Cytosolic NADP-IDH is one of the major producers of NADPH required for fatty acid and cholesterol biosynthesis in vertebrates (Koh et al., 2004). In Saccharomyces cerevisiae, there are three homologous but genetically distinct and differentially compartmentalized NADP-IDH isoenzymes: mitochondrial, cytosolic and peroxisomal (Lu \& McAlister-Henn, 2010). In contrast to yeast, mammalian cells contain a single non-mitochondrial isoenzyme of NADP-IDH that localizes to both the cytosol and peroxisomes (Minard et al., 1998; Geisbrecht \& Gould, 1999). This non-mitochondrial mammalian NADP-IDH contains a type I peroxisomal targeting sequence, an Ala-Lys-Leu tripeptide at the carboxyl terminus (Jennings et al., 1994; Geisbrecht \& Gould, 1999). However, the mechanisms and conditions influencing the distribution of this enzyme in the two different cellular compartments are still unknown.

IDH is also present in extracellular spaces, e.g. in bronchoalveolar lavage fluid, as was demonstrated by
Guo et al. (2005). IDH was also found in the plasma (Ellis \& Goldberg, 1971; Chung et al., 2001). These findings suggest extracellular metabolic functions of $\mathrm{IDH}$ (Mitchell et al., 2008). A protein map of Drosophila melanogaster larvae hemolymph was obtained by Guedes et al. (2003) and IDH was identified there.

It has been demonstrated that IDH may interact with other proteins. An interaction between NAD-IDH and mitochondrial $\alpha$-ketoglutarate dehydrogenase was shown by Porpaczy et al. (1987). Hatakeyama et al. (2004) using S100A12-affinity chromatography identified cytosolic NADP-IDH as an S100A12-binding protein. This protein is a member of the S100 family of proteins containing two EF-hand calcium-binding motifs. S100 proteins have been found to interact in a $\mathrm{Ca}^{2+}$-dependent manner with proteins involved in cell proliferation and differentiation, cellular architecture, signal transduction, and intracellular metabolism (Hatakeyama et al., 2004).

It is worthy of note that NADP-IDH is expressed mainly in lipogenic tissues such as liver and adipocytes (Koh et al., 2004), whereas JHBP is expressed in insect fat body, a tissue functionally resembling liver. Earlier, it has been shown that the cell membrane ATP synthase interacts with JHBP and presumably participates in JHBP export from the site of its synthesis to the hemolymph (Zalewska et al., 2009). This process was found to be JH-dependent. Similarly, the binding of JHBP to apolipophorin, arylphorin and hexamerin was different in the presence and absence of $\mathrm{JH}$, which suggested that these proteins participate in transport of the JHBP-JH complex to the target tissues. This allowed us to postulate a model of JHBP transport from fat body cells to the target tissues in a JH-dependent manner (Zalewska et al., 2009). However, the interaction between IDH and JHBP does not seem to be dependent on the $\mathrm{JH}$ presence in the experimental conditions applied.

The JHBP molecule has a unique fold resembling the folding motif found in mammalian lipid binding proteins, bactericidal permeability-increasing protein (BPI) and cholesteryl ester transfer protein (CETP) (Beamer et al., 1997; Qiu et al., 2007), which also have an affinity to phospholipids. The molecule of JHBP contains two cavities (E, W) of almost the same size (Kolodziejczyk et al., 2008). There are some arguments, including ligand docking and chemical modification studies, that the W cavity forms the binding site for the hydrophobic JH molecule, with the N-terminal peptide of nine amino acids forming a lid which covers the cavity after hormone binding (Kolodziejczyk et al., 2008). Since the stoichiometry of JH binding to JHBP is $1: 1$, the role of the second cavity is a subject of discussion. However, it is known that this cavity is more hydrophilic at its edges than the W cavity (Kolodziejczyk et al., 2008). It seems that it can bind a phospolipid molecule. In this context it is interesting to note that IDH can interact with proteins which exhibit an affinity to phospolipids. Namely, analysis of $D$. melanogaster protein-protein interactions with a yeast two hybrid system has revealed that NADP-IDH interacts with six proteins, including a 14-3-3 protein (Giot et al, 2003). 14-3-3 protein isoforms have been found to associate to membranes (Martin et al., 1994; Roth et al., 1994) and phospholipid vesicles (Roth et al., 1994). Thus it is conceivable that JHBP may compete for a phospholipid bound to hemolymph lipid binding proteins forming a transient complex, and that this complex may contain IDH. 


\section{Acknowledgements}

This research was supported by a grant from the Ministry of Science and Higher Education 3018/B/ $\mathrm{P} 01 / 2009 / 37$.

\section{REFERENCES}

Beamer LJ, Carroll SF, Eisenberg D (1997) Crystal structure of human BPI and two bound phospholipids at 2.4 Angstrom resolution. Science 276: 1861-1864.

Ceccarelli C, Grodsky NB, Ariyaratne N, Colman RF, Bahnson BJ (2002) Crystal structure of porcine mitochondrial $\mathrm{NADP}^{+}$-dependent isocitrate dehydrogenase complexed with $\mathrm{Mn}^{2+}$ and isocitrate. J Biol Chem 277: 43454-43462.

Chung YH, Jung SA, Song BC, Chang WY, Kim JA, Song IH, Kim JW, Choi WB, Shong YK, Lee YS, Suh DJ (2001) Plasma isocitrate dehydrogenase as a marker of centrilobular hepatic necrosis in patients with hyperthyroidism. J Clin Gastroenterol 33: 118-122.

Contreras-Shannon V, Lin AP, McCammon MT, McAlister-Henn L (2005) Kinetic properties and metabolic contributions of yeast mitochondrial and cytosolic $\mathrm{NADP}^{+}$-specific isocitrate dehydrogenases. J Biol Chem 280: 4469-4475.

Daniel TO, Schneider WJ, Goldstein JL, Brown MS (1983) Visualization of lipoprotein receptors by ligand blotting. J Biol Chem 258: 4606-4611.

Duk M, Krotkiewski H, Forest E, Rodriguez Parkitna J, Kochman M, Lisowska E (1996) Evidence for glycosylation of the juvenilehormone-binding protein from Galleria mellonella hemolymph. Eur J Biochem 242: 741-746.

Ellis G, Goldberg DM (1971) An improved manual and semi-automatic assay for NADP-dependent isocitrate dehydrogenase activity, with a description of some kinetic properties of human liver and serum enzyme. Clin Biochem 2: 175-185.

Geisbrecht BV, Gould SJ (1999) The human PICD gene encodes a cytoplasmic and peroxisomal $\mathrm{NADP}^{+}$-dependent isocitrate dehydrogenase. J Biol Chem 274: 30527-30533.

Gilbert I, Granger NA, Roe RM (2000) The juvenile hormones: historical facts and speculations on future research directions. Insect Biochem Mol Biol 30: 617-644.

Giot L, Bader JS, Brouwer C, Chaudhuri A, Kuang B, Li Y, Hao YL, Ooi CE, Godwin B, Vitols E, Vijayadamodar G, Pochart P, Machineni H, Welsh M, Kong Y, Zerhusen B, Malcolm R, Varrone Z, Collis A, Minto M, Burgess S, McDaniel L, Stimpson E, Spriggs F, Williams J, Neurath K, Ioime N, Agee M, Voss E, Furtak K, Renzulli R, Aanensen N, Carrolla S, Bickelhaupt E, Lazovatsky Y, DaSilva A, Zhong J, Stanyon CA, Finley Jr RL, White KP, Braverman M, Jarvie T, Gold S, Leach M, Knight J, Shimkets RA, McKenna MP, Chant J, Rothberg JM (2003) A protein interaction map of Drosophila melanogaster. Science 302: 1727-1736.

Guedes Sde M, Vitorino R, Tomer K, Domingues MR, Correia AJ, Amado F, Domingues P (2003) Drosophila melanogaster larval hemolymph protein mapping. Biochem Biophys Res Commun 312: 545-554.

Guo Y, Ma SF, Grigoryev D, Van Eyk J, Garcia JG (2005) 1-DE MS and 2-D LC-MS analysis of the mouse bronchoalveolar lavage proteome. Proteomics 5: 4608-4624.

Hatakeyama T, Okada M, Shimamoto S, Kubota Y, Kobayashi R (2004) Identification of intracellular target proteins of the calciumsignaling protein S100A12. Eur J Biochem 271: 3765-3775.

Hidayat P, Goodman WG (1994) Juvenile hormone and hemolymph juvenile hormone binding protein titers and their interaction in the hemolymph of fourth stadium Manduca sexta. Insect Biochem Mol Biol 24: 709-715.

Jennings GT, Sechi S, Stevenson PM, Tuckey RC, Parmelee D, McAlister-Henn L (1994) Cytosolic NADP ${ }^{+}$-dependent isocitrate dehydrogenase. Isolation of rat cDNA and study of tissue-specific and developmental expression of mRNA. J Biol Chem 269: 23128-23134.

Jo SH, Son MK, Koh HJ, Lee SM, Song IH, Kim YO, Lee YS, Jeong KS, Kim WB, Park JW, Song BJ, Huh TL (2001) Control of mitochondrial redox balance and cellular defense against oxidative damage by mitochondrial $\mathrm{NADP}^{+}$-dependent isocitrate dehydrogenase. $J$ Biol Chem 276: 16168-16176.

Koh HJ, Lee SM, Son BG, Lee SH, Ryoo ZY, Chang KT, Park JW, Park DC, Song BJ, Veech RL, Song H, Huh TL (2004) Cytosolic
$\mathrm{NADP}^{+}$-dependent isocitrate dehydrogenase plays a key role in lipid metabolism. J Biol Chem 279: 39968-39974.

Kolodziejczyk R, Bujacz G, Jakób M, Ożyhar A, Jaskolski M, Kochman M (2008) Insect juvenile hormone binding protein shows ancestral fold present in human lipid-binding proteins. J Mol Biol 377: 870-881.

Kort CAD, Granger NA (1996) Regulation of JH titers: The relevance of degradative enzymes and binding proteins. Arch Insect Biochem Physiol 33: 1-26.

Krzyżanowska D, Lisowski M, Kochman M (1998) UV-difference and CD spectroscopy studies on juvenile hormone binding to its carrier protein. J Pept Res 51: 96-102.

Laemmli UK (1970) Cleavage of structural proteins during the assembly of the head of bacteriophage T4. Nature 227: 680-685.

Lu Q, Minard KI, McAlister-Henn L (2008) Dual compartmental localization and function of mammalian $\mathrm{NADP}^{+}$-specific isocitrate dehydrogenase in yeast. Arch Biochem Biophys 472: 17-25.

Lu Q, McAlister-Henn L (2010) Peroxisomal localization and function of $\mathrm{NADP}^{+}$-specific isocitrate dehydrogenases in yeast. Arch Biochem Biophys 493: 125-134.

Martin H, Rostas J, Patel Y, Aitken A (1994) Subcellular localisation of 14-3-3 isoforms in rat brain using specific antibodies. I Neurochem 63: 2259-2265.

Minard KI, Jennings GT, Loftus TM, Xuan D, McAlister-Henn L (1998) Sources of NADPH and expression of mammalian $\mathrm{NADP}^{+}$-specific isocitrate dehydrogenases in Saccharomyces cerevisiae. J Biol Chem 273: 31486-31493.

Mitchell GB, Clark ME, Siwicky M, Caswell JL (2008) Stress alters the cellular and proteomic compartments of bovine bronchoalveolar lavage fluid. Vet Immunol Immunopathol 125: 111-125.

Ożyhar A, Kochman M (1987) Juvenile-hormone-binding protein from the hemolymph of Galleria mellonella (L). Isolation and characterization. Eur J Biochem 162: 675-682.

Porpaczy Z, Sumegi B, Alkonyi I (1987) Integration between NADdependent isocitrate dehydrogenase, alpha-ketoglutarate dehydrogenase complex, and NADH: ubiquinone oxidoreductase. J Biol Chem 262: 9509-9514.

Qiu X, Mistry A, Ammirati MJ, Chrunyk BA, Clark RW, Cong Y, Culp JS, Danley DE, Freeman TB, Geoghegan KF, Griffor MC, Hawrylik SJ, Hayward CM, Hensley P, Hoth LR, Karam GA, Lira ME, Lloyd DB, McGrath KM, Stutzman-Engwall KJ, Subashi AK, Subashi TA, Thompson JF, Wang IK, Zhao H, Seddon AP (2007) Crystal structure of cholesteryl ester transfer protein reveals a long tunnel and four bound lipid molecules. Nat Struct Mol Biol 14: 106113.

Rodriguez Parkitna JM, Ożyhar A, Wiśniewski JR, Kochman M (2002) Cloning and sequence analysis of Galleria mellonella juvenile hormone binding protein — a search for ancestors and relatives. Biol Chem. 383: 1343-1355.

Roth D, Morgan A, Martin H, Jones D, Martens GJ, Aitken A, Burgoyne RD (1994) Characterization of 14-3-3 proteins in adrenal chromaffin cells and demonstration of isoform-specific phospholipid binding. Biochem J 301: 305-310.

Sehnal F, Slama K (1966) The effect of corpus allatum hormone on respiratory metabolism during larval development and metamorphosis of Galleria mellonella. I Insect Physiol 12: 1333-1342.

Shevchenko A, Wilm M, Vorm O, Mann M (1996) Mass spectrometric sequencing of proteins silver-stained polyacrylamide gels. Anal Chem 68: $850-858$.

Thompson JD, Higgins DG, Gibson TJ (1994) ClustalW: improving the sensitivity of progressive multiple sequence alignment through sequence weighting, position-specific gap penalties and weight matrix choice. Nucleic Acids Res 22: 4673-4680.

Towbin H, Staehelin T, Gordon J (1979) Electrophoretic transfer of proteins from polyacrylamide gels to nitrocellulose sheets: procedure and some applications. Proc Natl Acad Sci USA 76: 4350-4354.

Wieczorek E, Kochman M (1991) Conformational change of the haemolymph juvenile hormone-binding protein from Galleria mellonella (L). Eur J Biochem 201: 347-353.

Wieczorek E, Rodriguez Parkitna JM, Szkudlarek J, Ożyhar A, Kochman M (1996) Immunoaffinity purification of juvenile hormonebinding protein from Galleria mellonella hemolymph. Acta Biochim Pol 43: $603-610$.

Zalewska M, Kochman A, Estève JP, Lopez F, Chaoui K, Susini C, Ożyhar A, Kochman M (2009) Juvenile hormone binding protein traffic - Interaction with ATP synthase and lipid transfer proteins. Biochim Biophys Acta Biomembran 1788: 1695-1705. 